University for Business and Technology in Kosovo

UBT Knowledge Center

UBT International Conference

2015 UBT International Conference

Nov 7th, 9:00 AM - 5:00 PM

\title{
E-customer relationship management in insurance industry in
}

\section{Albania}

\author{
Evelina Bazini \\ University of Vlora, evelina.bazini@univlora.edu.al
}

Follow this and additional works at: https://knowledgecenter.ubt-uni.net/conference

Part of the Databases and Information Systems Commons, and the Information Security Commons

\section{Recommended Citation}

Bazini, Evelina, "E-customer relationship management in insurance industry in Albania" (2015). UBT International Conference. 114.

https://knowledgecenter.ubt-uni.net/conference/2015/all-events/114

This Event is brought to you for free and open access by the Publication and Journals at UBT Knowledge Center. It has been accepted for inclusion in UBT International Conference by an authorized administrator of UBT Knowledge Center. For more information, please contact knowledge.center@ubt-uni.net. 


\title{
E-customer relationship management in insurance industry in Albania
}

\author{
Evelina Bazini \\ University of Vlora "Ismail Qemali“", Faculty of Economy \\ Albania \\ evelina.bazini@univlora.edu.al
}

\begin{abstract}
E- Customer relationship management is an issue that every company, large or small must take in some way. Handled well, a CRM strategy can deliver significant benefits for companies and customers. Interaction with customers, in particular, has been enhanced and organizations who wish to remain competitive have started to implement CRM programmes and techniques in order to develop closer relations with their customers and to develop a better understanding of their needs. At the same time, the use of e-commerce techniques in CRM allows insurance organizations to identify customers, monitor their habits and use of information, and deliver them improved information and services according to their recognized needs and buying behavior. This paper looks at new developments in e-CRM in the insurance industry.
\end{abstract}

Keywords: e-customer relationship management, insurance industry, ICT.

\section{Introduction}

Over the last two decades, the insurance industry has experienced remarkable changes in its organizational structure due to the increased use of the Internet in business processes. The advent of the Internet, along with increasing globalization and growing competition have brought fundamental changes in the way information about insurance products is distributed and delivered. The Internet and other ICTs offer extraordinary opportunities for innovation in customer relations management. These technologies may empower customer choice and offer unprecedented amounts of information about customer needs and desires. They offer new means for customers to find product and service information, to negotiate purchases, to make enquiries about the conditions of sale and support for their purchases, and to track deliveries and requests. For businesses, e-CRM provides new ways to recruit customers and retain their loyalty, to customize services and provide personalized products and services, to identify emerging patterns of demand in style and to enhance links with suppliers to meet these demands. E-CRM is a good candidate for a systematic examination of organizational and technological innovation because of the diversity and potential impact of the opportunities it provides.

\section{Literature review}

\subsection{Insurance services ${ }^{2}$}

According to the Encyclopaedia Britannica, insurance is "a contract for reducing losses from accident incurred by an individual party through a distribution of the risk of such losses among a number of parties." The definition goes on to say: "In return for a specified consideration, the insurer undertakes to pay the insured or his beneficiary some specified amount in the event that the insured suffers loss through the occurrence of a contingent event covered by the insurance contract or policy. By pooling both the financial contributions and the 'insurable risks' of a large number of policyholders, the insurer is typically able to absorb losses incurred over any given period much more easily than would the uninsured individual" (Encyclopaedia Britannica, Micropaedia, 1987, p. 335). A briefer definition of insurance as a phenomenon is "the practice of sharing among many persons, risks to life or property 
that would otherwise be suffered by only a few. This is effected by each person paying a sum of money called a premium which, with those paid by all the others, is put into a 'pool' or insurance fund, out of which money is paid to the few who suffer loss" (Longman Dictionary of Business English, 1989). The policyholder thus pays someone else a premium to bear his or her risk, knowing that a possible future loss will be compensated for according to the premium paid. If lucky, the policyholder will never have to experience the tangible results of the service of reduced risk during the contracted policy period. On the other hand, the policyholder maintains a certain uncertainty towards the service that he or she pays for, something that adds to the peculiarity of insurance services.

\subsection{Relationship marketing in an insurance environment ${ }^{2}$}

A relationship marketing approach allows the insurance marketer to offer a product in response to needs triggered by the customer and based on experience and information gathered over time. Sales and profitability can be dramatically increased because the more a marketer knows about a customer the more effectively the customer can be approached with appropriately targeted products (Harrison, 1993).One of the major themes in relationship marketing, as well as a key to profitability, is to develop long-term relationships with customers. This involves the ability to retain customers, and is in turn, dependent on agents possessing the "right" characteristics. What is "right" varies depending on whether the customer is an individual or a company. In insurance language these two types of customers may be called personal lines policyholders and commercial lines policyholders respectively

\subsection{E-customer relationship management ${ }^{7}$}

E- CRM describes the broad range of technologies used to support a company's CRM strategy. It can be seen to arise from the consolidation of traditional CRM with the e-business applications marketplace. Lee Kelley et al. (2003, p. 24) highlight the relative lack of literature in this domain and suggest as a working definition that e-CRM refers to 'the marketing activities, tools and techniques delivered via the Internet which includes email, world wide web, chat rooms, e-forums, etc., with a specific aim to locate, build and improve long term customer relationships to enhance their individual potential'. Typically electronic and interactive media such as the Internet and email are seen as playing the most significant role in operationalizing CRM as they support effective customized information between the organization and customers. However, e-CRM can also include other e-technologies and new e-channels including mobile telephony, customer call and contact centers and voice response systems. The use of these technologies and channels means that companies are managing customer interactions with either no human contact at all, or involving reduced levels of human intermediation on the supplier side (Anon, 2002). The emergence of mobile commerce has led to the introduction of new products, new ways of selling products to customers and new learning curves for companies in terms of how to manage interactions with customers (Wright et al., 2002).

\section{The Albanian insurance market ${ }^{8}$}

Insurance affects significantly economic growth because through risk management instruments it promotes efficient investments. The Albanian Insurance Market is a new market, dynamic and with continuous emerging developments. Insurances in Albania are relatively a young field though their inception dates in 1900. The well-known Londoner insurance company Lloyd's had branches in Durresi, Vlora and Shengjin. Insurance market in Albania has passed through several stages:

First stage - dates on the Second World War, when all insurances activities where carried out by foreign companies (Londoner, Italian \& French). Italian companies acting in Albania were Assicurazione General, Reunione Adriatica, Fonderia Di Firencia Tirana, Instituto Italiana di Previsone, and Roberto Alegro Vlore etc. Italian companies covered insurance activities related with natural disasters in premises, industries and life: Introducing for the first time the insurance concept in the albanian life.

Second Stage - lasts from 1944 to 1991. In that time during a meeting the Ministers Council determined the obligatory insurance of government property, while for the private property, insurance was enforced by law. Objectives, risks, premiums, regulation and other conditions related with insurances were approved by the Finance Ministery over the proposals of Savings \& Insurance 
Institute. During this stage it is impossible to discuss about real insurance market in Albania. The economy was centralized, so every gathered premium was used according to a plan by the state. It was impossible for the institution to have its own investment portfolio.

Third stage - from July 1991 up to no. The big changes that happened in the Albanian life had their reflections in the economic life, and following this also in the insurance field.

In 31 July 1991, the ministers' council approved the law nr 7506, according to which, the Savings and Insurance institute, would split up in two different institutions: Savings Bank and Insurance Institute named also INSIG. INSIG the first Albanian insurance company was created as a commercial enterprise and acted in compliance with market economy rules. A very important step in reformation and liberalization of the insurance system in Albanian played also the law nr 8081 dated on 07.03.1996 "For the insurances and/or reinsurances activities".

\section{Methodology of research}

The data presented in this paper come from an exploratory study involving detailed interviews with a variety of leading industry actors in the insurance industry using a structured interview questionnaire. The questionnaire was designed to serve as the basis for qualitative rather than quantitative research. Specifically, it was intended to collect qualitative information about the status of e-CRM and trends in the tourism service industry and also to embrace the views of those involved directly in CRM. The questionnaire results were processed anonymously and the interviewee data have been treated confidentially. The research methodology enabled the collection of both qualitative and quantitative information about a number of trends surrounding the emergence of e-CRM in the insurance industry. Overall, competition within the insurance industry is becoming more and more intense.

\section{Research findings}

Although most interviewees stressed that it is too early to assess the impact of e-CRM methods on customer relations, they felt that their companies' performance in relation to customer retention and satisfaction had improved as a result of their online presence. Several barriers and constraints were identified in the adoption of e-CRM including the maturity of the market to which companies address their products and services, the financial resources required, and the prevailing structures and modes of practice within organizations which inhibit the establishment of new business routines.

These findings suggest that although the majority of surveyed companies value e-CRM and have started to commit resources to relevant initiatives, few companies have actually been engaged in mature, long term planning regarding e-CRM proper adoption and use. However, the real challenge for insurance companies in order to realize productivity gains is the automation of their back office operations. The challenge therefore is not to implement technology-based CRM solutions but to establish the associated organizational and cultural (customer-centered service provision) change within companies that would allow CRM to contribute to productivity and profitability.

Functional changes associated with e-CRM adoption - The majority of companies in the sample were in the process of unravelling their e-CRM development plans and were not prepared to comment on the changes in the functions of their organization as they had not been in a position to fully exploit the expected opportunities. E-business methods enable a company to grow without developing its physical distribution network. At the same time, all companies papered that customer relations have become stronger and more 'personal' with the use of e-CRM, as the technology allows them to contact customers individually in a fast and cheap way and to receive frequent feedback from them.

Gaining and retaining customers - The interviewees' responses to alternative e-business methods for identifying, gaining and interacting with customers. These may include online promotion campaigns, maintaining a customer database, customer profiling, setting up interactive questionnaires, and tracking the choices of customers while they surf on the website. The responses show that companies are particularly keen on maintaining customer databases and less keen on setting up interactive questionnaires, which as suggested are often treated as a nuisance by the customers.

The ability to collect, combine, maintain, and process data from a multiplicity of sources is central to gaining a richer view of customers, their needs, and the value they can generate for the company. 
Bringing together data from different sources is a critical task for insurance companies that wish to develop a better understanding of their customers. A model that has been proposed for the evolution of customer databases involves three stages: In the first stage, data are stored in electronic format by each department of the organization and/or by type of application without the possibility for crosschecking and information sharing. The next stage involves the development of 'links' between the different databases so that when a customer's record is updated in one system, it automatically passes the information onto the others. The third and more advanced stage involves the development of a data warehouse system which has sufficient intelligence to perform more complicated tasks such as analyzing customer data and assessing the value of a customer.

Support customer information needs - Interviewees agreed that Internet websites provide richer and more-up-to-date information than any other physical distribution channel. For the majority of companies the web serves as a primary source of information and marketing tool for their services. E-catalogues are cost-effective, can be more detailed than paper catalogues, and are friendly to use even for customers with basic Internet skills. Some interviewees expressed the view that soon they will replace paper-printed brochures.

Organizational impact of e-CRM adoption - The adoption of e-business methods in customer relations signaled organizational changes in most of the companies in the sample. Some companies established a special department within the organization. The department usually consists of a working team of people dedicated to set up and maintain the website and the sales over the Internet.

Although most interviewees stressed that it is too early to assess the impact of e-CRM methods on customer relations, they felt that their companies' performance in relation to customer retention and satisfaction had improved as a result of their online presence.

Perceived barriers and future trends - In their early steps toward e-CRM, the insurance companies that took part in the research identified several barriers and constraints. These mainly related to:

- $\quad$ The maturity of the market to which they address their products and services

- The financial resources required, and

- The prevailing structures and modes of practice within organizations.

An additional inhibiting factor identified by company representatives was the size of investments required for the introduction of e-CRM given that the industry generally operates with low margins. A customer-focused strategy driven by the use of new technology requires large investments that need to be justified to shareholders and compensated in a reasonable period of time. Apart from the conflicts that arise with traditional distribution networks of insurance agents, a further constraint relates to the prevailing organizational structure within companies. Companies were not always ready to adopt and exploit new ways of doing things. Some interviewees papered resistance to change by some departments, which slowed the adoption process. A minimum level of agreement on a common vision is necessary to get things started and an orchestrated effort is required so that internal conflicts between new and traditional sale methods are eliminated.

The barriers identified above have made many companies take a step-by-step approach in implementing e-business methods. Such a cautious strategy is expected to take into account a company's identity and image with customers as well as an assessment of possible impacts and results. Despite some skepticism, the majority of companies responded positively as to whether they intend to extend e-business in the organization within the next five years. An argument put forward is that 'what is acceptable by e-commerce methods now, will expand as clients get used to, and confident with the medium so this may present scope for expansion'. Others considered further expansion of ebusiness initiatives to be a strategic choice for their companies as to the way to become leading players in the online market. Only a small number of interviewees argued that such plans fall within normal business practice.

\section{Conclusions and recommendations}

The research findings indicate that companies in the insurance industry in Albania are just beginning to experiment with e-CRM applications and to explore the business opportunities they entail. So far, these have remained largely untapped as witnessed by the fact that traditional sales methods still account for over $90 \%$ of their revenues. The competitive pressure to keep up with the new business environment appears to be a major factor driving e- CRM developments in the industry. 
Traditional and new players in the insurance industry see the Internet more as an efficient tool of communication and interface with customers than as a fundamentally new way of doing business. The availability of services online offers opportunities to companies in the insurance business to achieve cost reductions in operating costs and opens up an effective and direct communication channel with existing and potential customers. Managing the relationships with the network of independent agents, the purchasing groups, and their own off-line and online distribution networks emerged from the interviews as a fundamental problem suppliers in the insurance industry are facing. An alternative solution has been proposed that would reconcile the traditional with the new distribution channels and would turn the Internet into an ally instead of an enemy of insurance agents. For this to happen, the latter need to understand and value the complementary nature of online selling to traditional business practices.

The real challenge therefore is not to implement technology-based CRM solutions but to establish the necessary technological (data-warehouses and customer intelligence systems), organizational (data integration, inter-departmental communication, links with distributors and resellers) and cultural (customer-centered service provision) change within companies that would allow CRM to contribute to productivity and profitability.

\section{References}

1. Ahmed Mohiddin. (2002). The challenges of e-democracy. Opportunities and risks.

2. Bazini, E. Elmazi, L. \& Sinanaj, Sh. (2012). Importance of relationship management in the insurance business in AlbaniaProcedia - Social and Behavioral Sciences. Volume 44, Pages 1-482 (2012). ISSN: 1877-0428.

3. Bloch, M. and Y. Pigneur and T. Steiner (1996). The IT-enabled Extended Enterprise: Applications in the Tourism Industry. Stefan Klein et al. Information and Communication Technologies in Tourism. Ohrid : Macedonia

4. Buhalis, D. \& M.C.Licata (2001).The Future of e-Tourism Intermediaries. Journal of Tourism Management, 23(3): 207-220.

5. Buhalis, D. (1998). Strategic Use of Information Technologies in the Tourism Industry. Jornal of Tourism Management, 19(5): 409-421.

6. Dutta Soumitra \& Stephen Kwan \& Arie Segev (1997). Transforming Business in the Market space: Strategic Marketing and Customer Relationships. CITM.

7. Kennedy, A. Electronic Customer Relationship Management (eCRM): Opportunities and Challenges in a Digital World

8. Madani.F., Bazini.E., (2013). The role of Insurance companies in albanian economy Journal of Academic Research in Economics. Volume 5, Number 1, June 2013, 147-161. ISSN: 2066- 0855.

9. Mansell, R. \& W. E. Steinmueller (2000). Mobilizing the Information Society: Strategies for Growth and Opportunity. Oxford University Press.

10. Springer Verlag and Wien (1999). Information Technology and Tourism - A Challenging Relationship. USA 